\title{
Fremanezumab for preventive treatment of migraine
}

\section{Functional status on headache-free days}

Juliana VanderPluym, MD, David W. Dodick, MD, Richard B. Lipton, MD, Yuju Ma, MA, Pippa S. Loupe, PhD, and Marcelo E. Bigal, MD

Neurology ${ }^{\circledR}$ 2018;91:e1152-e1165. doi:10.1212/01.wnl.0000544321.19316.40

\section{Abstract}

\section{Objective}

To evaluate the effect of fremanezumab on the functional status on headache-free days in phase 2 episodic migraine (EM) and chronic migraine (CM) studies.

\section{Methods}

Functional status data were collected prospectively via the electronic headache diary on all headache-free days by patients answering questions regarding work/school/household chore performance, speed of work completion, concentration, and feeling of fatigue. Individuals with EM receiving monthly doses of fremanezumab $225 \mathrm{mg}(\mathrm{n}=96)$ or $675 \mathrm{mg}(\mathrm{n}=97)$ or placebo $(\mathrm{n}=104)$ were compared. Individuals with CM receiving fremanezumab $675 \mathrm{mg}$ followed by monthly $225 \mathrm{mg}(\mathrm{n}=88)$ and $900 \mathrm{mg}(\mathrm{n}=86)$ were also independently compared to those receiving placebo $(n=89)$.

\section{Results}

In patients with EM, compared to patients receiving placebo, those receiving fremanezumab experienced an increased number of headache-free days with normal function in work/school/ household chore performance and concentration/mental fatigue measures compared to their baseline over the entire treatment period (all $p<0.005$ ). An increased number of headache-free days with normal functional performance for some measures was also found in the CM group in those treated with fremanezumab.

\section{Conclusion}

There was an increased number of headache-free days with normal functional performance on all measures for the patients with EM and some measures for patients with CM in the fremanezumab-treated groups. Further research is required to confirm these findings in a prospective study and to clarify the underlying mechanism(s).

\section{ClinicalTrials.gov identifier:}

NCT02025556 and NCT02021773.

\section{Classification of evidence}

This study provides Class II evidence that for patients with migraine, fremanezumab increases normal functional performance on headache-free days.

\author{
Correspondence \\ Dr. VanderPluym \\ VanderPluym.Juliana@ \\ mayo.edu
}

\section{MORE ONLINE}

$\rightarrow$ Class of Evidence

Criteria for rating

therapeutic and diagnostic studies

NPub.org/coe

\section{- CME Course}

NPub.org/cmelist

From the Mayo Clinic (J.V., D.W.D.), Phoenix, AZ; Montefiore Headache Center (R.B.L.), Albert Einstein College of Medicine, New York, NY; Teva Pharmaceuticals Ltd (Y.M., P.S.L.), Netanya, Israel; and Teva Pharmaceuticals Ltd (M.E.B.), Frazer, PA. Dr. Bigal is now at Purdue Pharma, Stamford, CT.

Go to Neurology.org/N for full disclosures. Funding information and disclosures deemed relevant by the authors, if any, are provided at the end of the article. 


\section{Glossary}

ANCOVA = analysis of covariance; $\mathbf{C G R P}=$ calcitonin gene-related peptide; $\mathbf{C M}=$ chronic migraine; $\mathbf{E M}=$ episodic migraine; HFEM = high-frequency episodic migraine; $\mathbf{M M R M}=$ mixed-effects model repeated measurement.

Episodic migraine (EM) affects $12 \%$ of the general population, and $\approx 1 \%$ of the general population experiences chronic migraine $(\mathrm{CM})$, defined as headaches occurring on at least $15 \mathrm{~d} / \mathrm{mo}$, with at least 8 days of migraine per month. ${ }^{1-4}$ On the basis of disability associated with the headache attacks, migraine is ranked seventh highest among medical causes of disability worldwide. ${ }^{5}$

Headache-related disability may incompletely capture the burden of migraine because growing evidence suggests that the effect of migraine extends beyond the headache. In a recent large study ${ }^{6}$ investigating 2,959 patients with EM, 10.6\% reported interictal anxiety, $14.8 \%$ reported avoidance and lifestyle compromise, and $26 \%$ reported interictal symptoms. Rather than the conventional view of migraine as an episodic or paroxysmal headache disorder with attacks that are divided into discrete phases in between which patients are symptomfree, migraine may be best conceptualized as a chronic neurologic disorder with persistent interparoxysmal physiologic compromise, exemplified by persistent symptoms punctuated by recurrent attacks of headache and other attack-related symptoms that may include overlapping phases of prodrome (commonly referred to as premonitory), aura, headache, and postdrome..$^{7-9}$ Prodrome and postdrome symptoms are indeed common, affecting up to $80 \%$ of the migraine population. ${ }^{10-12}$ Accounting for phase-related and interictal nonheadache symptoms, in addition to the symptoms of frequent comorbid diseases, is important in fully describing the burden of migraine.

Fremanezumab, formerly known as TEV-48125, is a fully humanized immunoglobulin G2a monoclonal antibody that potently and selectively binds to calcitonin generelated peptide (CGRP), thereby preventing its binding to receptors. Phase 2 and pivotal phase 3 trials assessing its efficacy and safety have been completed for EM and $\mathrm{CM}^{13-17}$ In the trials, patients completed a daily headache calendar; in days that they did not experience headaches, patients answered questions focused on functional performance for the day. Here, we take advantage of the phase 2 fremanezumab trials to evaluate its effect on functional performance on headache-free days.

\section{Primary research question}

Do patients with migraine taking fremanezumab have improved functional performance on headache-free days? This study provides Class II evidence that for patients with migraine, fremanezumab increases headache-free days with normal functional performance.

\section{Standard protocol approvals, registrations, and patient consents}

The high-frequency EM (HFEM) and CM phase 2 studies were conducted in accordance with the Good Clinical Practice and the US Food and Drug Administration guidelines for safety monitoring and were registered at clinicaltrials.gov as NCT02025556 and NCT02021773. All patients provided written informed consent before enrolling in the study, and all protocols were approved by institutional review committees for each site. The studies were conducted from January 2014 to January 2015 at 62 sites in the United States, including headache centers, neurology clinics, and primary care facilities.

\section{Study design and patients}

The current study is a post hoc analysis of data from the phase 2 trials assessing fremanezumab in the preventive treatment of HFEM and CM. ${ }^{13,14}$ In each study, 2 doses of fremanezumab were administered as 4 subcutaneous injections once a month for 3 months: monthly 225 or $675 \mathrm{mg}$ fremanezumab in the HFEM study and $675 \mathrm{mg}$ ( 1 initial loading dose) followed by monthly 225 or $900 \mathrm{mg}$ fremanezumab in the CM study.

Both studies evaluated patients 18 to 65 years of age. Eligible patients in the HFEM trial had HFEM, defined as 8 to 14 headache days per month, and were allowed to use 1 standard migraine preventive drug at stable doses for at least 3 months before study onset and acute migraine medications up to $14 \mathrm{~d} / \mathrm{mo}$ (maximum of 4 days of opioids or barbiturates). Eligible patients in the $\mathrm{CM}$ trial met International Classification of Headache Disorders III beta criteria for CM (defined as $>15$ headache days per month and could even have daily headache). ${ }^{4}$ They were allowed to use 2 different migraine preventive drugs at stable doses for at least 3 months before study entry and were allowed to treat their acute migraine headaches as usual. In both studies, patients needed to have $\geq 80 \%$ compliance with the recording of daily headache information using the electronic headache diary during the 28-day run-in phase. Patients were excluded if they received onabotulinumtoxinA during the 6 months before study entry, used opioids or barbiturates for $>4$ days during the run-in phase, or failed $\geq 3$ migraine preventive drugs in the past.

\section{Randomization and masking}

After meeting eligibility requirements in the 28-day run-in period, patients in the HFEM and CM trials were stratified on the basis of sex and preventive medication use, and then randomization (1:1:1) was done into either the placebo or 
1 of the 2 active treatment arms via an electronic interactive web response system that was accessed by the study coordinators through the eClinical Operating System portal, a Code of Federal Regulations-compliant permissions-based system. The randomization schema was developed centrally by a dedicated staff at the contract research organization who had no further role in the study.

Study sites were asked to have 2 blinded study coordinators at each clinic visit, 1 for clinical assessment and 1 for treatment administration. Patients were masked to treatment allocation; they all received 4 injections at each 28 -day treatment visit that were identical in packaging and appearance regardless of treatment group from blinded study coordinators.

\section{Procedures}

Daily information on the occurrence and nature of headaches was captured by the patient using the electronic diary. For each day, patients recorded data for the previous 24-hour period. The interactive web response system allowed 1 day of back-entering information and was locked thereafter. Headache information was recorded during the run-in phase and each of the three 28-day treatment periods.

\section{Outcomes and analyses}

For these post hoc analyses, headache-free days were defined as days in which a patient answered "no" to the question, "Did you experience a headache of any severity?" Functional performance data were collected prospectively via the electronic diary and were categorized into 1 of 2 categories: work/ school/household chore performance and concentration/ mental fatigue.

To assess performance at work, school, or home, patients were asked the following 2 questions and could answer by choosing normal, $<50 \%$ impaired, or $\geq 50 \%$ impaired: (1) Best describe your work/school performance yesterday; and (2) best describe your ability to perform household chores. To assess concentration/mental fatigue, patients were asked the following 3 questions and could choose none of the time, some of the time, most of the time, or all of the time: (1) How much of the time did you feel that you were working more slowly or taking longer to complete tasks? (2) How much of the time yesterday did you find it difficult to concentrate on what you needed to do? (3) On average, how much of the time yesterday were you very tired, asleep, or feeling drained?

Using analyses of covariance (ANCOVAs) and a mixedeffects model repeated measurement (MMRM) analyses (SAS version 9.2, SAS Institute, Cary, NC), we analyzed the change from baseline in the mean number of days each possible response was given per survey question. ANCOVAs measured the change in the mean number of days for each possible response from baseline to the entire treatment period (weeks 1-12). The MMRM analyses evaluated the change in the mean number of days for each possible response from baseline to the end of each monthly treatment period. The best possible responses indicating optimal status included being able to work/study normally, performing household chores normally, reporting no time working more slowly or taking longer to complete tasks, reporting no time with difficulty concentrating, and reporting no time feeling very tired, asleep, or feeling drained. All efficacy variables were analyzed by the modified intent-to-treat principle, which included all randomized participants who received at least 1 dose of study drug and provided at least 1 endpoint measurement. The ANCOVA model included treatment, sex, region, and baseline preventive medication use (yes/no) as fixed effects and baseline value and years since onset of migraine as covariates. The MMRM model included month and treatment-by-month interaction additionally. Because these were post hoc analyses, adjustments for multiple comparisons are not appropriate, ${ }^{18}$ and the results of the inference statistics should be considered exploratory in nature.

\section{Data availability}

The data for the post hoc analyses described in this report are available by request from the author investigators or Teva Pharmaceuticals Ltd, the company sponsoring the clinical development of fremanezumab for the treatment of migraine.

\section{Results}

\section{Patient disposition}

The HFEM and CM studies were conducted in parallel at the same sites, and a total of 1,170 patients were screened overall for both studies. For the HFEM study, 297 individuals met eligibility criteria and were randomized to receive placebo $(\mathrm{n}=104)$ or fremanezumab $225 \mathrm{mg}(\mathrm{n}=96)$ or $675 \mathrm{mg}(\mathrm{n}=97)$. For the CM study, 264 patients with CM were randomized to receive placebo $(\mathrm{n}=89)$ or fremanezumab $675 / 225 \mathrm{mg}(\mathrm{n}=$ $88)$ or $900 \mathrm{mg}(\mathrm{n}=87)$. The demographic characteristics of both studies are presented in table 1 . Patient disposition and reasons for withdrawal have been described previously. ${ }^{13,14}$

\section{Safety and efficacy}

Detailed results of the HFEM and CM phase 2 studies are described elsewhere. ${ }^{13,14}$ In brief, fremanezumab was shown to have a favorable safety profile and to be well tolerated, with no serious safety signals or clinically relevant changes in vital signs, ECG parameters, or laboratory findings. There were no differences in the rate of treatment-emergent adverse events with fremanezumab compared with placebo, with the exception of mild injection-site pain and pruritus. The rate of injection-site pain for the placebo groups in the HFEM and CM studies was $6 \%$ and $3 \%$, respectively, and for the fremanezumab groups was $6.8 \%$ and $8.0 \%$ respectively. The rate of pruritus was $0 \%$ for the placebo groups and $2 \%$ and $3.4 \%$ for the fremanezumab groups in the HFEM and CM study.

As previously described, fremanezumab significantly improved headache parameters such as the number of headache days and the number of migraine days for the duration of the 
Table 1 Baseline demographic and disease characteristics of patients in the HFEM and CM studies

\begin{tabular}{|c|c|c|c|c|c|c|}
\hline \multirow[b]{3}{*}{ Characteristics $^{a}$} & \multicolumn{3}{|c|}{ HFEM study } & \multicolumn{3}{|l|}{ CM study } \\
\hline & \multirow[b]{2}{*}{$\begin{array}{l}\text { Placebo } \\
(n=104)\end{array}$} & \multicolumn{2}{|c|}{ Fremanezumab } & \multirow[b]{2}{*}{$\begin{array}{l}\text { Placebo } \\
(n=89)\end{array}$} & \multicolumn{2}{|c|}{ Fremanezumab } \\
\hline & & $\begin{array}{l}225 \mathrm{mg} \\
(\mathrm{n}=96)\end{array}$ & $\begin{array}{l}675 \mathrm{mg} \\
(\mathrm{n}=97)\end{array}$ & & $\begin{array}{l}675 / 225 \mathrm{mg} \\
(\mathrm{n}=88)\end{array}$ & $\begin{array}{l}900 \mathrm{mg} \\
(\mathrm{n}=86)\end{array}$ \\
\hline Age, y & $42.0(11.6)$ & $40.8(12.4)$ & $40.7(12.6)$ & $40.7(11.5)$ & $40.0(11.6)$ & $41.5(12.9)$ \\
\hline Body mass index $\mathrm{kg} / \mathrm{cm}^{2}$ & $27.2(5.2)$ & $26.9(5.2)$ & $27.4(5.1)$ & $25.7(4.5)$ & $27.0(5.2)$ & $26.6(5.3)$ \\
\hline \multicolumn{7}{|l|}{ Sex n (\%) } \\
\hline Male & $12(12)$ & $9(9)$ & $15(15)$ & $13(15)$ & $12(14)$ & $12(14)$ \\
\hline Female & $92(88)$ & $87(91)$ & $82(85)$ & $76(85)$ & $76(86)$ & $75(86)$ \\
\hline \multicolumn{7}{|l|}{ Ethnic origin, n (\%) } \\
\hline White & $85(82)$ & $74(77)$ & $74(76)$ & $76(85.4)$ & 70 (79.6) & $73(83.9)$ \\
\hline Black/African American & $13(13)$ & $19(20)$ & $18(19)$ & $9(10.1)$ & $12(13.6)$ & $9(10.3)$ \\
\hline Asian & $2(2)$ & $1(1)$ & $1(1)$ & $1(1.1)$ & $0(0)$ & $0(0)$ \\
\hline Other & 0 & 0 & 0 & $3(3.4)$ & $6(6.8)$ & $5(5.8)$ \\
\hline Hours of headaches of any severity per month & $82.1(49.3)$ & $76.1(36.7)$ & $80.4(36.6)$ & $169.1(13.9)$ & $159.1(9.7)$ & $157.7(11.7)$ \\
\hline Headache days of any severity per month & $12.4(2.3)$ & $12.6(3.1)$ & $12.5(2.6)$ & $16.5(6.3)$ & $16.5(6.7)$ & $15.9(6.5)$ \\
\hline Headache days of at least moderate severity per month & $9.8(2.7)$ & $10.0(3.1)$ & $9.6(2.9)$ & $13.9(5.6)$ & $13.8(6.3)$ & $13.1(5.9)$ \\
\hline Days of acute medication use & $10.4(3.6)$ & $10.4(3.6)$ & $9.8(4.0)$ & $15.7(6.2)$ & $15.1(7.0)$ & $16.2(6.7)$ \\
\hline Years of migraines, mean (SD) & $21(14.1)$ & $18.9(12.9)$ & $16.9(12.3)$ & $20.4(13.1)$ & $15.8(11.2)$ & $18.8(12.2)$ \\
\hline \multicolumn{7}{|l|}{ Preventive medicine use, $\mathrm{n}(\%)$} \\
\hline Yes & $28(27)$ & $32(34)$ & $26(27)$ & $38(42.7)$ & 35 (39.7) & 33 (37.9) \\
\hline No & $76(73)$ & $64(66)$ & $71(73)$ & $51(57.3)$ & $53(60.2)$ & $54(62.1)$ \\
\hline
\end{tabular}

Abbreviations: $\mathrm{CM}=$ chronic migraine; HFEM = high-frequency episodic migraine.

${ }^{a}$ Mean (SD) values are provided unless otherwise noted.

study and at early endpoints with significant efficacy compared with placebo after 1 week of treatment. ${ }^{16,17}$ In the HFEM study, the mean number of headache-free days at month 3 is 19.7 (SD 4.9) for the placebo group, 22.1 (SD 4.7) for fremanezumab $225 \mathrm{mg}$ group, and 21.8 (SD 4.9) for the fremanezumab $675 \mathrm{mg}$ group. For the CM study, the mean number of headache-free days at month 3 is 12.5 (SD 7.9) for placebo, 15.0 (SD 8.2) for fremanezumab $675 / 225 \mathrm{mg}$, and 15.7 (SD 8.2) for fremanezumab $900 \mathrm{mg}$.

\section{Functional status}

The results of the ANCOVA least square mean (standard error) post hoc analyses on the changes from baseline to the end of the treatment period for the responses to questions on functional status on headache-free days are shown in table 2 . In the HFEM study group, we found differences between the fremanezumab groups and placebo group in the change from baseline to end of treatment in the number of headache-free days in which patients reported that they worked/studied normally and performed household chores normally (all $p<$ 0.005). There were treatment differences in the number of headache-free days in which patients reported no time working more slowly, no time with difficulty in concentrating, and no time feeling very tired, asleep, or feeling drained (all $p<0.005$ ).

In the CM study, for those receiving the 900-mg dose, we found consistent differences compared to those receiving placebo in the number of headache-free days with responses indicating optimal status (worked/studied normally $p=$ 0.011 , performed household chores normally $p=0.0007$, and reported no time working more slowly $p=0.0076$, having difficulty concentrating $p=0.0162$, or feeling very tired $p=$ 0.0322 ). For the patients in the $675 / 225-\mathrm{mg}$ dose group, there were differences compared to placebo in the number of headache-free days in which patients performed household chores normally $(p=0.0465)$ and reported having no time having difficulty concentrating $(p=0.0284)$. Although changes in the number of headache-free days in which patients reported having work/study and household chore performance impaired by $\geq 50 \%$ or reported having difficulty in concentrating most of the time were minimum (i.e., $<1$ day for all groups), there were increases in the 675/225-mg group 
Table 2 Changes in patient-reported measures from baseline to end of the 3-month treatment period on headache-free days for the 2 domains of functional performance Change from baseline in number of headache-free days with:

\begin{tabular}{|c|c|c|c|c|c|c|}
\hline \multirow{3}{*}{$\begin{array}{l}\text { ANCOVA: LSM (SE) } \\
\text { (minimum-maximum), p } \\
\text { value, placebo vs } \\
\text { fremanezumab dose }\end{array}$} & \multicolumn{3}{|l|}{ HFEM study } & \multicolumn{3}{|l|}{ CM study } \\
\hline & \multirow[b]{2}{*}{ Placebo $(n=104)$} & \multicolumn{2}{|l|}{ Fremanezumab } & \multirow[b]{2}{*}{ Placebo $(n=89)$} & \multicolumn{2}{|l|}{ Fremanezumab } \\
\hline & & $225 \mathrm{mg}(\mathrm{n}=95)$ & $675 \mathrm{mg}(\mathrm{n}=96)$ & & $675 / 225 \mathrm{mg}(n=87)$ & $900 \mathrm{mg}(\mathrm{n}=85)$ \\
\hline $\begin{array}{l}\text { Change from baseline } \\
\text { number of headache-free } \\
\text { days at month } 3\end{array}$ & $4.0(0.47)$ & $6.8(0.50)$ & $6.4(0.52)$ & $5.4(0.69)$ & $8.1(0.78)$ & $8.3(0.74)$ \\
\hline \multicolumn{7}{|l|}{$\begin{array}{l}\text { Work/study/chore } \\
\text { performance }\end{array}$} \\
\hline Worked/studied normally & $1.60(0.72)(0.18$ to 3.02$)$ & $\begin{array}{l}4.76(0.71)(3.37 \text { to } 6.14) \\
p=0.0002\end{array}$ & $\begin{array}{l}4.34(0.69)(2.99 \text { to } 5.70) \\
p=0.0012\end{array}$ & $3.48(0.77)(1.97$ to 5.00$)$ & $\begin{array}{l}4.34(0.85)(2.66 \text { to } 6.03) \\
p=0.3801\end{array}$ & $\begin{array}{l}6.05(0.84)(4.39 \text { to } 7.71) \\
p=0.0111\end{array}$ \\
\hline $\begin{array}{l}\text { Work/studied impaired } \\
<50 \%\end{array}$ & $0.71(0.43)(-0.14$ to 1.57$)$ & $\begin{array}{l}0.08(0.42)(-0.76 \text { to } 0.91) \\
p=0.1942\end{array}$ & $\begin{array}{l}0.37(0.41)(-0.44 \text { to } 1.18) \\
p=0.4951\end{array}$ & $0.71(0.40)(-0.07$ to 1.50$)$ & $\begin{array}{l}1.49(0.44)(0.62 \text { to } 2.37) \\
p=0.1271\end{array}$ & $\begin{array}{l}1.08(0.44)(0.22 \text { to } 1.94) \\
p=0.4731\end{array}$ \\
\hline $\begin{array}{l}\text { Work/studied impaired } \\
\geq 50 \%\end{array}$ & $0.45(0.16)(0.14$ to 0.75$)$ & $\begin{array}{l}0.20(0.15)(-0.10 \text { to } 0.49) \\
p=0.1555\end{array}$ & $\begin{array}{l}0.48(0.15)(0.19 \text { to } 0.77) \\
p=0.8733\end{array}$ & $0.08(0.13)(-0.17$ to 0.32$)$ & $\begin{array}{l}0.43(0.14)(0.15 \text { to } 0.70) \\
p=0.0302\end{array}$ & $\begin{array}{l}0.15(0.14)(-0.12 \text { to } 0.43) \\
p=0.6241\end{array}$ \\
\hline $\begin{array}{l}\text { Performed household } \\
\text { chores normally }\end{array}$ & $1.73(0.67)(0.42$ to 3.04$)$ & $\begin{array}{l}4.98(0.68)(3.65 \text { to } 6.32) \\
p<0.0001\end{array}$ & $\begin{array}{l}4.54(0.65)(3.26 \text { to } 5.83) \\
p=0.0003\end{array}$ & $3.22(0.67)(1.90$ to 4.54$)$ & $\begin{array}{l}4.88(0.69)(3.53 \text { to } 6.23) \\
p=0.0465\end{array}$ & $\begin{array}{l}6.07(0.69)(4.71 \text { to } 7.42) \\
p=0.0007\end{array}$ \\
\hline $\begin{array}{l}\text { Ability to perform } \\
\text { household chores was } \\
\text { impaired by }<50 \%\end{array}$ & $0.51(0.39)(-0.27$ to 1.29$)$ & $\begin{array}{l}-0.21(0.40)(-1.00 \text { to } 0.58) \\
p=0.1109\end{array}$ & $\begin{array}{l}0.20(0.37)(-0.56 \text { to } 0.96) \\
p=0.4878\end{array}$ & $1.13(0.36)(0.43$ to 1.84$)$ & $\begin{array}{l}1.26(0.36)(0.54 \text { to } 1.97) \\
p=0.7753\end{array}$ & $\begin{array}{l}0.68(0.37)(-0.03 \text { to } 1.40) \\
p=0.3058\end{array}$ \\
\hline $\begin{array}{l}\text { Ability to perform } \\
\text { household chores was } \\
\text { impaired } \geq 50 \%\end{array}$ & $0.18(0.12)(-0.06$ to 0.42$)$ & $\begin{array}{l}-0.04(0.13)(-0.29 \text { to } 0.20) \\
p=0.1114\end{array}$ & $\begin{array}{l}0.14(0.12)(-0.10 \text { to } 0.38) \\
p=0.7658\end{array}$ & $-0.18(0.11)(-0.40$ to 0.05$)$ & $\begin{array}{l}0.15(0.12)(-0.08 \text { to } 0.39) \\
p=0.0211\end{array}$ & $\begin{array}{l}0.20(0.12)(-0.43 \text { to } 0.04) \\
p=0.8884\end{array}$ \\
\hline $\begin{array}{l}\text { Could not perform } \\
\text { household chores }\end{array}$ & $0.03(0.06)(-0.09$ to 0.14$)$ & $\begin{array}{l}0.07(0.06)(-0.05 \text { to } 0.19) \\
p=0.5059\end{array}$ & $\begin{array}{l}0.10(0.06)(-0.02 \text { to } 0.22) \\
p=0.2769\end{array}$ & $0.10(0.08)(-0.05$ to 0.25$)$ & $\begin{array}{l}0.22(0.08)(0.06 \text { to } 0.37) \\
p=0.2075\end{array}$ & $\begin{array}{l}0.00(0.08)(-0.15 \text { to } 0.16) \\
p=0.30\end{array}$ \\
\hline \multicolumn{7}{|l|}{$\begin{array}{l}\text { Difficulty in concentration } \\
\text { or mental fatigue }\end{array}$} \\
\hline $\begin{array}{l}\text { No time working more } \\
\text { slowly or taking longer to } \\
\text { complete tasks }\end{array}$ & 1.51 (0.71) (0.11 to 2.91$)$ & $\begin{array}{l}5.33(0.69)(3.96 \text { to } 6.70) \\
p<0.0001\end{array}$ & $\begin{array}{l}5.34(0.68) \text { (4.01 to } 6.67) \\
p<0.0001\end{array}$ & $3.39(0.72)$ (1.98 to 4.80$)$ & $\begin{array}{l}4.97(0.79)(3.40 \text { to } 6.53) \\
p=0.0848\end{array}$ & $\begin{array}{l}5.91(0.79)(4.36 \text { to } 7.46) \\
p=0.0076\end{array}$ \\
\hline $\begin{array}{l}\text { Some of the time working } \\
\text { more slowly or taking } \\
\text { longer to complete tasks }\end{array}$ & 1.26 (0.49) (0.29 to 2.23$)$ & $\begin{array}{l}-0.28(0.48)(-1.23 \text { to } 0.67) \\
p=0.0062\end{array}$ & $\begin{array}{l}-0.36(0.47)(-1.30 \text { to } 0.54) \\
p=0.0043\end{array}$ & $0.99(0.45)(0.10$ to 1.88$)$ & $\begin{array}{l}1.42(0.49)(0.43 \text { to } 2.40) \\
p=0.4552\end{array}$ & $\begin{array}{l}1.02(0.49)(0.06 \text { to } 1.99) \\
p=0.954\end{array}$ \\
\hline $\begin{array}{l}\text { Half of time or more } \\
\text { working more slowly or } \\
\text { taking longer to complete } \\
\text { task }\end{array}$ & $-0.01(0.12)(-0.25$ to 0.23$)$ & $\begin{array}{l}-0.09(0.12)(-0.32 \text { to } 0.15) \\
p=0.586\end{array}$ & $\begin{array}{l}0.08 \text { (0.12) }(-0.15 \text { to } 0.31) \\
p=0.5094\end{array}$ & $0.01(0.10)(-0.19$ to 0.21$)$ & $\begin{array}{l}0.08(0.11)(-0.15 \text { to } 0.30) \\
p=0.6046\end{array}$ & $\begin{array}{l}0.23(0.11)(0.01 \text { to } 0.46) \\
p=0.0897\end{array}$ \\
\hline
\end{tabular}




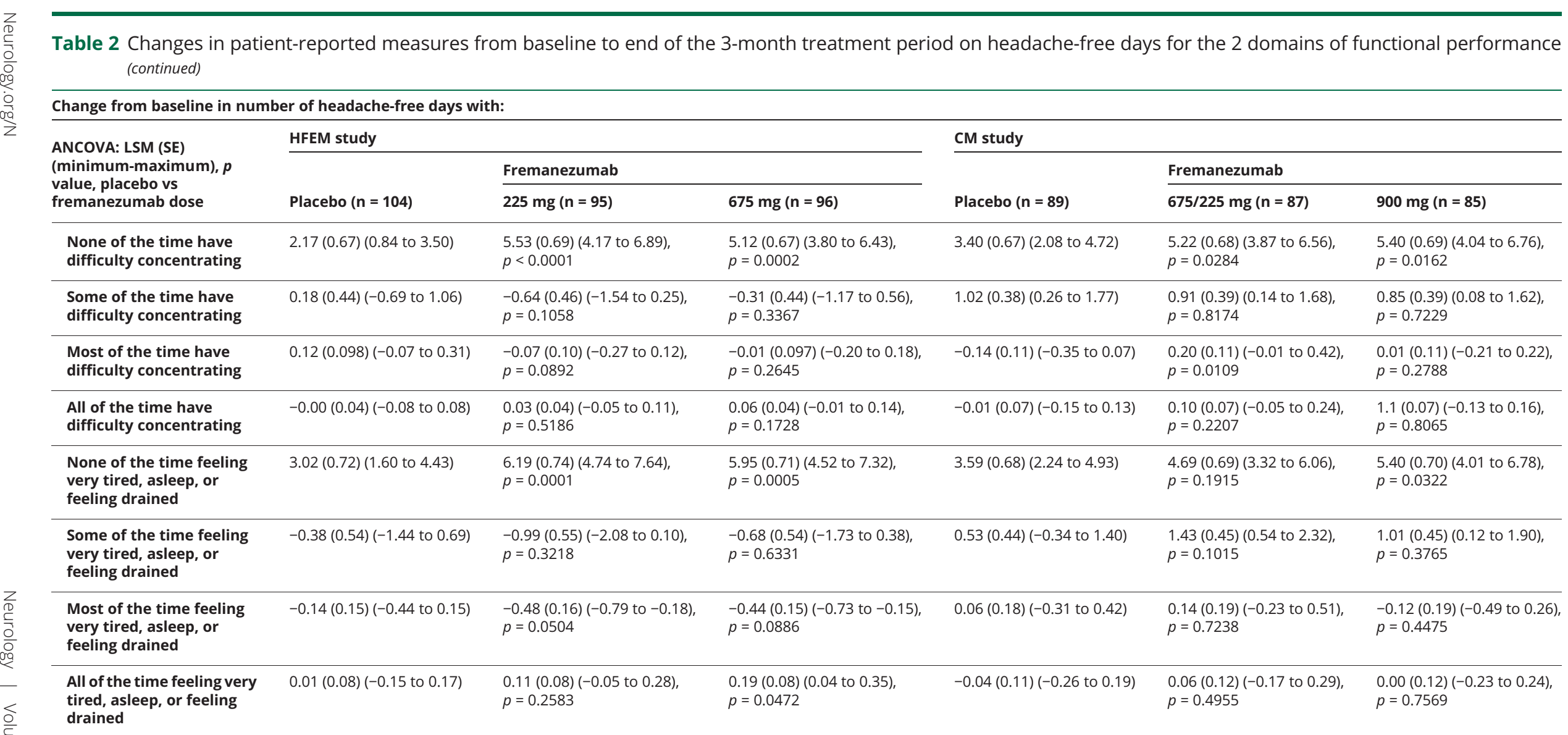

Abbreviations: ANCOVA = analysis of covariance; $C M$ = chronic migraine; $H F E M=$ high-frequency episodic migraine; $L S M=$ least square mean . 
compared to the placebo group $(p=0.0302, p=0.0211$, and $p$ $=0.0109$, respectively; table 2 ).

\section{Functional status during each monthly fremanezumab treatment period}

The results of the MMRM analyses on the changes from baseline during each monthly treatment period for responses indicating optimal status are described below and illustrated in figures 1 and 2. The data for the full results for all possible responses are available in table 3.

As shown in figure 1, the change scores indicate that the number of headache-free days in which patients were able to perform work/study and household chores normally relative to their pretreatment baseline increased during each month of fremanezumab treatment. For the CM study, although there were increases in the number of headache-free days with work/study and household chores performed normally for both fremanezumab groups, there were only marginal effects shown for the 900-mg group.

Patients in the HFEM study in the 225- and 675-mg groups reported increased number of headache-free days compared to placebo in which they were not working more slowly or reported no difficulty in concentrating, not feeling very tired, or not feeling drained during each treatment period (figure 2, all $p<0.001$, except $675 \mathrm{mg}$ at month $2, p<0.01$ for no difficulty in concentrating). For the CM study, there were increases in headache-free days in which patients reported no time with difficulty in concentrating and no time feeling very tired, asleep, or feeling drained during each of the 3 monthly treatment periods for the 900-mg dose (all $p<0.05$ except for month 3 for no time working more slowly and no time feeling very tired).

\section{Discussion}

Patients taking fremanezumab in the HFEM and CM trials reported an increased number of headache-free days with normal functional performance compared to placebo within the domains of work or school, household work, and chores, as well as energy and ability to concentrate. In the HFEM trial, increases in headache-free days with normal functional performance with 225- and 675-mg doses of fremanezumab were seen. In the CM trial, increases in headache-free days with

Figure 1 Patient responses to questions concerning work/school/chore performance
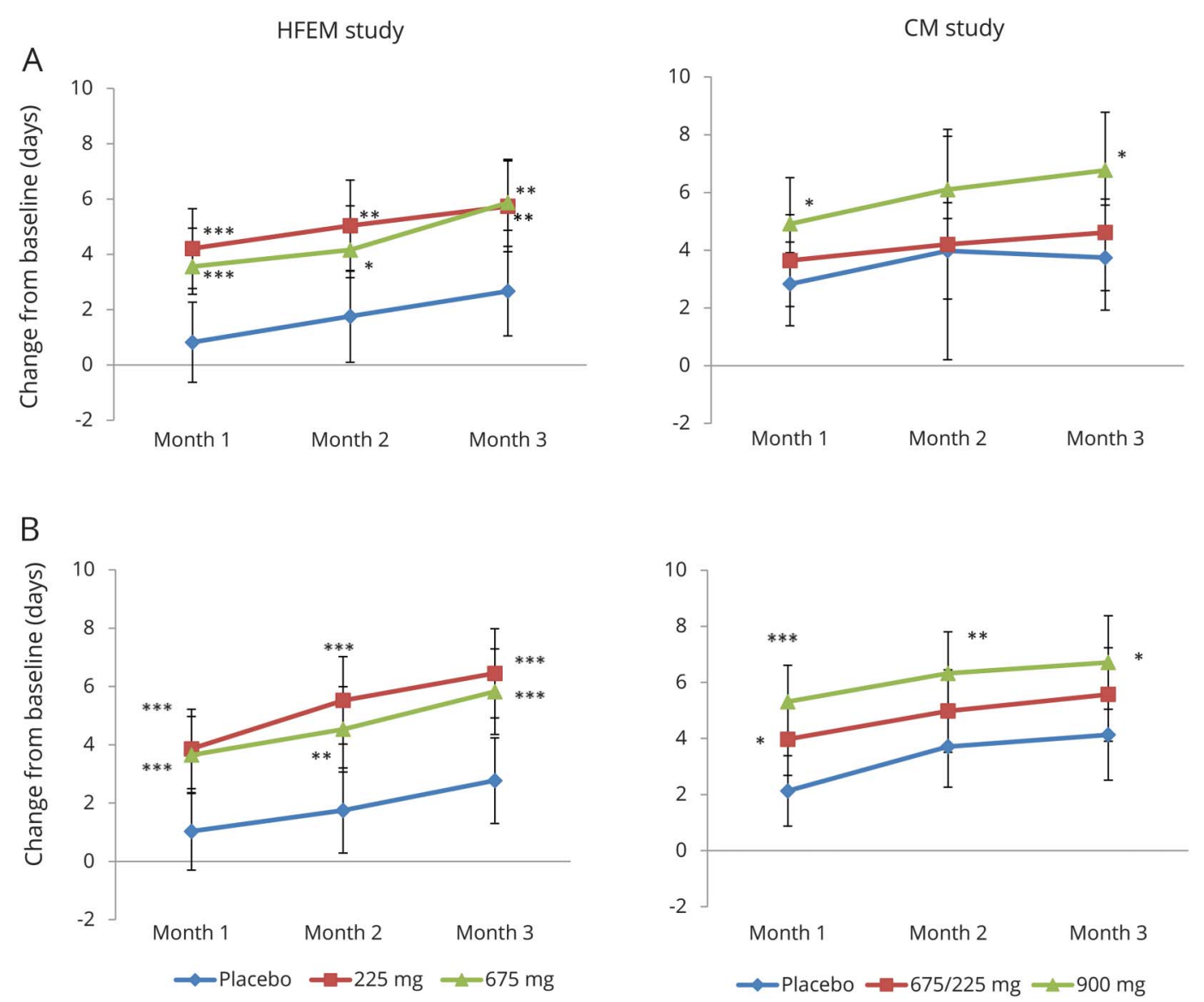

(A) Work/school performance: I worked/studied normally. (B) Best describe your ability to perform household chores: I performed household chores normally. $\mathrm{CM}=$ chronic migraine; HFEM = high-frequency episodic migraine. ${ }^{*} p<0.05,{ }^{* *} p<0.01,{ }^{*} *{ }^{*} p<0.001$. 
Figure 2 Patient responses to questions on having difficulty in concentration and mental fatigue
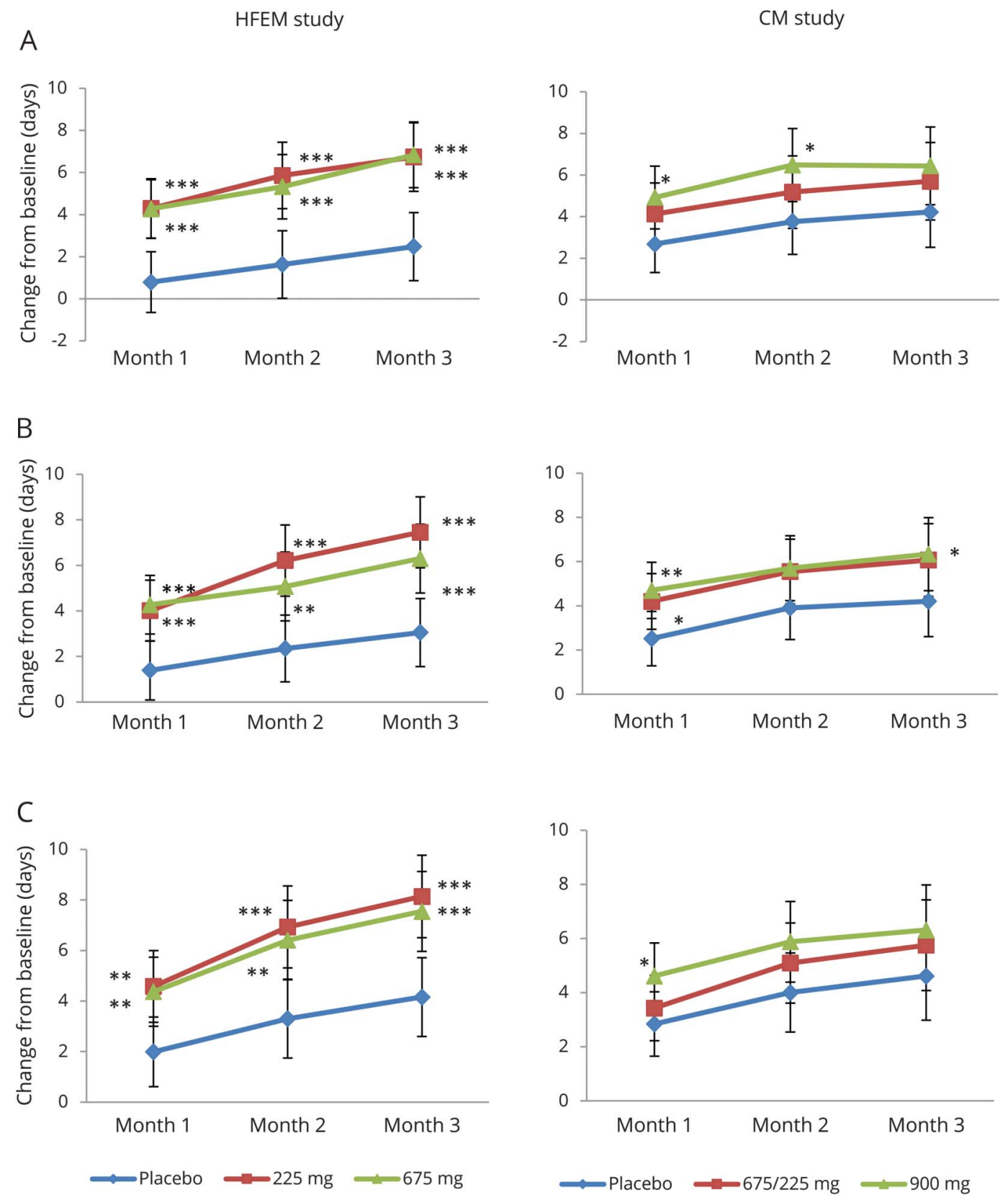

(A) How much time did you feel that you were working more slowly or taking longer to complete a task? None of the time. (B) How much of the time yesterday did you find it difficult to concentrate on what you needed to do? None of the time. (C) On average, how much of the time yesterday were you very tired, asleep,

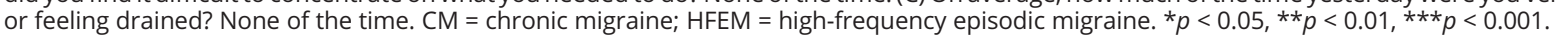

normal functional performance were seen mostly with the 900-mg dose of fremanezumab.

Because these findings come from post hoc analyses performed to examine functional status on headache-free days for patients treated with fremanezumab during the HFEM and CM phase 2 studies, the results should be considered exploratory. Further research is needed to confirm these preliminary findings and to understand the factors contributing to perceived functional status on headache-free days. Dissecting these factors will be critical to understanding the total burden of migraine for patients and identifying how treatments like fremanezumab could potentially address some of them. One could postulate that patients had more headachefree days with normal functional performance simply because they had more headache-free days on fremanezumab. With increased headache-free days, patients may have had reduced interictal anxiety and thus reduced avoidance behavior and lifestyle compromise, allowing them to function normally. This is a testable hypothesis for future studies. Notably, we did not see a consistent increase in headache-free days when patients on active treatment reported lower levels of 
Table 3 MMRM analyses results on functional performance measures

Change from baseline in number of headache-free days with:

\begin{tabular}{|c|c|c|c|c|c|c|c|c|c|}
\hline \multirow[b]{4}{*}{$\begin{array}{l}\text { MMRM analyses: LSM (SE), } p \text { value, } \\
\text { placebo vs fremanezumab dose }\end{array}$} & \multicolumn{9}{|c|}{ Change from baseline in number of headache-free days with: } \\
\hline & \multicolumn{9}{|c|}{ HFEM study } \\
\hline & \multicolumn{3}{|l|}{ Month 1} & \multicolumn{3}{|l|}{ Month 2} & \multicolumn{3}{|l|}{ Month 3} \\
\hline & $\begin{array}{l}\text { Placebo } \\
(n=104)\end{array}$ & $\begin{array}{l}225 \mathrm{mg} \\
(\mathrm{n}=95)\end{array}$ & $\begin{array}{l}675 \mathrm{mg} \\
(\mathrm{n}=96)\end{array}$ & $\begin{array}{l}\text { Placebo } \\
(n=104)\end{array}$ & $\begin{array}{l}225 \mathrm{mg} \\
(\mathrm{n}=95)\end{array}$ & $\begin{array}{l}675 \mathrm{mg} \\
(\mathrm{n}=96)\end{array}$ & $\begin{array}{l}\text { Placebo } \\
(n=104)\end{array}$ & $\begin{array}{l}225 \mathrm{mg} \\
(\mathrm{n}=95)\end{array}$ & $\begin{array}{l}675 \mathrm{mg} \\
(\mathrm{n}=96)\end{array}$ \\
\hline \multicolumn{10}{|l|}{ Work/study/chore performance } \\
\hline Worked/studied normally & $0.82(0.74)$ & $\begin{array}{l}4.21(0.73) \\
p=0.0001\end{array}$ & $\begin{array}{l}3.56(0.71) \\
p=0.002\end{array}$ & $1.76(0.85)$ & $\begin{array}{l}5.04(0.84) \\
p=0.0019\end{array}$ & $\begin{array}{l}4.16(0.81) \\
p=0.0232\end{array}$ & $2.67(0.83)$ & $\begin{array}{l}5.74(0.83) \\
p=0.003\end{array}$ & $\begin{array}{l}5.87(0.80) \\
p=0.002\end{array}$ \\
\hline Worked/studied impaired $<50 \%$ & $0.77(0.41)$ & $\begin{array}{l}-0.34(0.40) \\
p=0.0189\end{array}$ & $\begin{array}{l}0.18(0.39) \\
p=0.2114\end{array}$ & $0.52(0.51)$ & $\begin{array}{l}0.39(0.50) \\
p=0.8326\end{array}$ & $\begin{array}{l}0.45(0.49) \\
p=0.9076\end{array}$ & $0.60(0.53)$ & $\begin{array}{l}0.39(0.54) \\
p=0.7534\end{array}$ & $\begin{array}{l}0.28(0.52) \\
p=0.6297\end{array}$ \\
\hline Worked/studied impaired $\geq 50 \%$ & $0.46(0.15)$ & $\begin{array}{l}0.24(0.15) \\
p=0.2183\end{array}$ & $\begin{array}{l}0.48(0.15) \\
p=0.9182\end{array}$ & $0.56(0.17)$ & $\begin{array}{l}0.10(0.17) \\
p=0.0277\end{array}$ & $\begin{array}{l}0.49(0.16) \\
p=0.7346\end{array}$ & $0.28(0.17)$ & $\begin{array}{l}0.26(0.17) \\
p=0.9086\end{array}$ & $\begin{array}{l}0.42(0.17) \\
p=0.5076\end{array}$ \\
\hline $\begin{array}{l}\text { Performed household chores } \\
\text { normally }\end{array}$ & $1.03(0.68)$ & $\begin{array}{l}3.86(0.69) \\
p=0.0004\end{array}$ & $\begin{array}{l}3.65(0.67) \\
p=0.001\end{array}$ & $1.75(0.74)$ & $\begin{array}{l}5.52(0.77) \\
p<0.0001\end{array}$ & $\begin{array}{l}4.53(0.74) \\
p=0.0024\end{array}$ & $2.77(0.75)$ & $\begin{array}{l}6.45(0.78) \\
p<0.0001\end{array}$ & $\begin{array}{l}5.82(0.75) \\
p=0.001\end{array}$ \\
\hline $\begin{array}{l}\text { Ability to perform household chores } \\
\text { impaired }<50 \%\end{array}$ & $0.40(0.37)$ & $\begin{array}{l}-0.19(0.37) \\
p=0.1574\end{array}$ & $\begin{array}{l}-0.15(0.36) \\
p=0.1928\end{array}$ & $0.49(0.44)$ & $\begin{array}{l}-0.35(0.45) \\
p=0.1258\end{array}$ & $\begin{array}{l}0.22(0.44) \\
p=0.6205\end{array}$ & $0.19(0.44)$ & $\begin{array}{l}-0.42(0.46) \\
p=0.2717\end{array}$ & $\begin{array}{l}0.26(0.45) \\
p=0.9051\end{array}$ \\
\hline $\begin{array}{l}\text { Ability to perform household chores } \\
\text { impaired } \geq 50 \%\end{array}$ & $0.20(0.12)$ & $\begin{array}{l}-0.11(0.12) \\
p=0.0322\end{array}$ & $\begin{array}{l}0.11(0.12) \\
p=0.5331\end{array}$ & $0.16(0.17)$ & $\begin{array}{l}-0.01(0.18) \\
p=0.4377\end{array}$ & $\begin{array}{l}0.27(0.17) \\
p=0.6441\end{array}$ & $0.22(0.15)$ & $\begin{array}{l}-0.06(0.16) \\
p=0.1565\end{array}$ & $\begin{array}{l}0.02(0.16) \\
p=0.3115\end{array}$ \\
\hline Could not perform household chores & $0.02(0.06)$ & $\begin{array}{l}0.03(0.07) \\
p=0.9505\end{array}$ & $\begin{array}{l}0.09(0.06) \\
p=0.3795\end{array}$ & $-0.02(0.09)$ & $\begin{array}{l}0.00(0.09) \\
p=0.8446\end{array}$ & $\begin{array}{l}0.16(0.09) \\
p=0.1245\end{array}$ & $-0.03(0.08)$ & $\begin{array}{l}0.14(0.08) \\
p=0.1213\end{array}$ & $\begin{array}{l}0.03(0.08) \\
p=0.6136\end{array}$ \\
\hline \multicolumn{10}{|l|}{$\begin{array}{l}\text { Difficulty in concentration or mental } \\
\text { fatigue }\end{array}$} \\
\hline $\begin{array}{l}\text { No time working more slowly or } \\
\text { taking longer to complete tasks }\end{array}$ & $0.79(0.73)$ & $\begin{array}{l}4.29(0.72) \\
p<0.0001\end{array}$ & $\begin{array}{l}4.27(0.70) \\
p<0.0001\end{array}$ & $1.63(0.81)$ & $\begin{array}{l}5.86(0.81) \\
p<0.0001\end{array}$ & $\begin{array}{l}5.33(0.78) \\
p=0.0003\end{array}$ & $2.48(0.82)$ & $\begin{array}{l}6.74(0.83) \\
p<0.0001\end{array}$ & $\begin{array}{l}6.84(0.79) \\
p<0.0001\end{array}$ \\
\hline $\begin{array}{l}\text { Some of the time working more } \\
\text { slowly or taking longer to complete } \\
\text { tasks }\end{array}$ & $1.22(0.49)$ & $\begin{array}{l}-0.13(0.49) \\
p=0.0202\end{array}$ & $\begin{array}{l}-0.35(0.47) \\
p=0.0076\end{array}$ & $1.09(0.54)$ & $\begin{array}{l}-0.30(0.54) \\
p=0.0343\end{array}$ & $\begin{array}{l}-0.48(0.52) \\
p=0.0178\end{array}$ & $1.09(0.57)$ & $\begin{array}{l}-0.47(0.57) \\
p=0.0275\end{array}$ & $\begin{array}{l}-0.53(0.55) \\
p=0.0217\end{array}$ \\
\hline $\begin{array}{l}\text { Half of the time working more slowly } \\
\text { or taking longer to complete tasks }\end{array}$ & $0.03(0.14)$ & $\begin{array}{l}-0.13(0.14) \\
p=0.3685\end{array}$ & $\begin{array}{l}0.07(0.14) \\
p=0.79\end{array}$ & $0.03(0.19)$ & $\begin{array}{l}-0.21(0.19) \\
p=0.3267\end{array}$ & $\begin{array}{l}0.28(0.18) \\
p=0.3096\end{array}$ & $-0.12(0.13)$ & $\begin{array}{l}0.09(0.13) \\
p=0.1872\end{array}$ & $\begin{array}{l}-0.05(0.13), \\
p=0.6624\end{array}$ \\
\hline $\begin{array}{l}\text { None of the time have difficulty } \\
\text { concentrating }\end{array}$ & $1.39(0.66)$ & $\begin{array}{l}4.01(0.68) \\
p=0.0008\end{array}$ & $\begin{array}{l}4.27(0.66) \\
p=0.0002\end{array}$ & $2.35(0.75)$ & $\begin{array}{l}6.21(0.77) \\
p<0.0001\end{array}$ & $\begin{array}{l}5.07(0.75) \\
p=0.0035\end{array}$ & $3.05(0.76)$ & $\begin{array}{l}7.45(0.79) \\
p<0.0001\end{array}$ & $\begin{array}{l}6.30(0.77) \\
p=0.0007\end{array}$ \\
\hline $\begin{array}{l}\text { Some of the time have difficulty } \\
\text { concentrating }\end{array}$ & $0.18(0.43)$ & $\begin{array}{l}-0.28(0.44) \\
p=0.363\end{array}$ & $\begin{array}{l}-0.72(0.43) \\
p=0.0735\end{array}$ & $-0.04(0.49)$ & $\begin{array}{l}-0.86(0.51) \\
p=0.1811\end{array}$ & $\begin{array}{l}-0.20(0.495) \\
p=0.7932\end{array}$ & $-0.00(0.51)$ & $\begin{array}{l}-1.34(0.53) \\
p=0.0373\end{array}$ & $\begin{array}{l}-0.18(0.51), \\
p=0.778\end{array}$ \\
\hline $\begin{array}{l}\text { Most of the time have difficulty } \\
\text { concentrating }\end{array}$ & $0.10(0.09)$ & $\begin{array}{l}-0.05(0.09) \\
p=0.1766\end{array}$ & $\begin{array}{l}-0.00(0.09) \\
p=0.3666\end{array}$ & $0.16(0.13)$ & $\begin{array}{l}-0.09(0.13) \\
p=0.151\end{array}$ & $\begin{array}{l}0.04(0.13) \\
p=0.4992\end{array}$ & $0.16(0.13)$ & $\begin{array}{l}-0.06(0.14) \\
p=0.222\end{array}$ & $\begin{array}{l}-0.05(0.14) \\
p=0.244\end{array}$ \\
\hline
\end{tabular}


Table 3 MMRM analyses results on functional performance measures (continued)

\begin{tabular}{|c|c|c|c|c|c|c|c|c|c|}
\hline \multirow[b]{4}{*}{$\begin{array}{l}\text { MMRM analyses: LSM (SE), } p \text { value, } \\
\text { placebo vs fremanezumab dose }\end{array}$} & \multicolumn{9}{|c|}{ Change from baseline in number of headache-free days with: } \\
\hline & \multicolumn{9}{|l|}{ HFEM study } \\
\hline & \multicolumn{3}{|l|}{ Month 1} & \multicolumn{3}{|l|}{ Month 2} & \multicolumn{3}{|l|}{ Month 3} \\
\hline & $\begin{array}{l}\text { Placebo } \\
(n=104)\end{array}$ & $\begin{array}{l}225 \mathrm{mg} \\
(\mathrm{n}=95)\end{array}$ & $\begin{array}{l}675 \mathrm{mg} \\
(\mathrm{n}=96)\end{array}$ & $\begin{array}{l}\text { Placebo } \\
(n=104)\end{array}$ & $\begin{array}{l}225 \mathrm{mg} \\
(\mathrm{n}=95)\end{array}$ & $\begin{array}{l}675 \mathrm{mg} \\
(\mathrm{n}=96)\end{array}$ & $\begin{array}{l}\text { Placebo } \\
(n=104)\end{array}$ & $\begin{array}{l}225 \mathrm{mg} \\
(\mathrm{n}=95)\end{array}$ & $\begin{array}{l}675 \mathrm{mg} \\
(\mathrm{n}=96)\end{array}$ \\
\hline $\begin{array}{l}\text { All of the time have difficulty } \\
\text { concentrating }\end{array}$ & $-0.01(0.04)$ & $\begin{array}{l}-0.01(0.04) \\
p=0.9421\end{array}$ & $\begin{array}{l}0.03(0.04) \\
p=0.45\end{array}$ & $-0.05(0.09)$ & $\begin{array}{l}-0.04(0.09) \\
p=0.9545\end{array}$ & $\begin{array}{l}0.16(0.09) \\
p=0.0985\end{array}$ & $-0.06(0.04)$ & $\begin{array}{l}0.04(0.04) \\
p=0.038\end{array}$ & $\begin{array}{l}-0.02(0.04), \\
p=0.3485\end{array}$ \\
\hline $\begin{array}{l}\text { None of the time feeling very tired, } \\
\text { asleep, or feeling drained }\end{array}$ & $1.99(0.70)$ & $\begin{array}{l}4.58(0.72) \\
p=0.0016\end{array}$ & $\begin{array}{l}4.37(0.70) \\
p=0.0038\end{array}$ & $3.30(0.79)$ & $\begin{array}{l}6.93(0.82) \\
p=0.0003\end{array}$ & $\begin{array}{l}6.41(0.80) \\
p=0.0017\end{array}$ & $4.16(0.79)$ & $\begin{array}{l}8.14(0.83) \\
p<0.0001\end{array}$ & $\begin{array}{l}7.55(0.80) \\
p=0.0007\end{array}$ \\
\hline $\begin{array}{l}\text { Some of the time feeling very tired, } \\
\text { asleep, or feeling drained }\end{array}$ & $-0.07(0.50)$ & $\begin{array}{l}-0.63(0.52) \\
p=0.3422\end{array}$ & $\begin{array}{l}-0.45(0.50) \\
p=0.5228\end{array}$ & $-0.81(0.59)$ & $\begin{array}{l}-1.19(0.61) \\
p=0.6063\end{array}$ & $\begin{array}{l}-1.03(0.59) \\
p=0.7634\end{array}$ & $-0.69(0.60)$ & $\begin{array}{l}-1.60(0.63) \\
p=0.229\end{array}$ & $\begin{array}{l}-0.93(0.61), \\
p=0.7473\end{array}$ \\
\hline $\begin{array}{l}\text { Most of the time feeling very tired, } \\
\text { asleep, or feeling drained }\end{array}$ & $-0.21(0.16)$ & $\begin{array}{l}-0.35(0.17) \\
p=0.4909\end{array}$ & $\begin{array}{l}-0.39(0.16) \\
p=0.8151\end{array}$ & $-0.02(0.18)$ & $\begin{array}{l}-0.53(0.19) \\
p=0.0316\end{array}$ & $\begin{array}{l}-0.42(0.19) \\
p=0.0886\end{array}$ & $-0.26(0.19)$ & $\begin{array}{l}-0.71(0.20) \\
p=0.0671\end{array}$ & $\begin{array}{l}-0.52(0.19), \\
p=0.281\end{array}$ \\
\hline $\begin{array}{l}\text { All of the time feeling very tired, } \\
\text { asleep, or feeling drained }\end{array}$ & $0.01(0.08)$ & $\begin{array}{l}0.10(0.08) \\
p=0.3749\end{array}$ & $\begin{array}{l}0.21(0.08) \\
p=0.0404\end{array}$ & $0.00(0.10)$ & $\begin{array}{l}0.02(0.11) \\
p=0.8756\end{array}$ & $\begin{array}{l}0.27(0.11) \\
p=0.0489\end{array}$ & $0.02(0.12)$ & $\begin{array}{l}0.31(0.12) \\
p=0.0672\end{array}$ & $\begin{array}{l}0.11(0.12) \\
p=0.5536\end{array}$ \\
\hline
\end{tabular}

Change from baseline in number of headache-free days with:

MMRM analyses: LSM (SE), $p$ value,

Month 1

placebo vs fremanezumab dose

Placebo

Placebo

( $n=89$ )

$\begin{array}{ll}675 / 225 \mathrm{mg} & 900 \mathrm{mg} \\ (n=87) & (n=85)\end{array}$

\section{Month 2}

Work/study/chore performance

Worked/studied normally

$2.83(0.73)$

( $\mathrm{n}=87$ )

$(\mathrm{n}=85)$

Placebo
$(n=89)$

$675 / 225 \mathrm{mg}$

(n $=87$ )
(n)

Month 3

Placebo
$(n=89)$

675/225 m

$675 / 225$
$(n=87)$

$900 \mathrm{mg}$

$(n=85)$

$3.74(0.92)$

$4.61(1.02)$

$(n=85)$

\begin{tabular}{ll} 
& $2.83(0.73)$ \\
\hline Worked/studied impaired $<50 \%$ & $0.49(0.38)$
\end{tabular}

$3.64(0.80)$
$p=0.3834$

$4.91(0.81)$

$3.98(0.85)$

$4.20(0.93)$

$6.10(0.94)$

$\begin{array}{ll}1.20(0.42), & 1.30(0.43), \\ p=0.148 & \quad P=0.1063\end{array}$

$0.61(0.50)$

$p=0.8502$

$p=0.067$

Worked/studied impaired $\geq 50 \%$

$0.05(0.11) \quad 0.25(0.12)$

$p=0.1063$

$2.13(0.55)$
$p=0.0272$

$1.38(0.56)$,

$3.74(0.92)$

$4.61(1.02)$
$p=0.4845$

$6.77(1.02)$

Performed household chores $p=0.157$

$p=0.8472$

$-0.06(0.12)$ $=0.0272$ $p=0.2653$

$1.37(0.54)$

$1.96(0.59)$, $p=0.0181$

normally

$2.13(0.64)$

3.97 (0.65),

5.31 (0.66),

Ability to perform household chores

impaired $<50 \%$

Ability to perform household chores

$1.29(0.36)$

$1.24(0.37)$ $p<0.0001$ $p=0.0197$

$0.12(0.13)$,

$0.08(0.17)$

$1.08(0.59)$
$p=0.7044$

impaired $\geq 50 \%$

$-0.28(0.11)$

$1.24(0.37)$,
$p=0.9095$

$0.51(0.37)$,
$p=0.0817$

$-0.00(0.12)$,

$-0.12(0.12)$,
$p=0.2519$

$3.71(0.74)$

$\begin{array}{ll}4.98(0.75), & 6.32(0.754) \\ P=0.1793 & P=0.0061\end{array}$ $p=0.2735$

$0.58(0.19)$

$0.11(0.19)$, $p=0.0061$

$4.13(0.823)$

$5.57(0.84)$ $p=0.9105$

$p=0.251$

0.90

$0.90(0.43)$

$1.81(0.44)$,
$p=0.1038$

$0.92(0.44)$,
$p=0.9664$

$0.20(0.13)$
$p=0.0721$

$-0.27(0.14)$
$p=0.399$

$p=0.399$

$1.34(0.48)$

$p=0.1875$

$6.71(0.85)$ $p=0.0184$

$-0.12(0.13)$

$p=0.0721$

$-0.06(0.17)$

$1.18(0.49)$
$p=0.7939$

$0.79(0.49)$ $p=0.3808$

$\begin{array}{ll}0.15(0.17), & -0.26(0.18), \\ p=0.3742 & p=0.3922\end{array}$


Table 3 MMRM analyses results on functional performance measures (continued)

Change from baseline in number of headache-free days with:

\begin{tabular}{|c|c|c|c|c|c|c|c|c|c|}
\hline \multirow[b]{4}{*}{$\begin{array}{l}\text { MMRM analyses: LSM (SE), } p \text { value, } \\
\text { placebo vs fremanezumab dose }\end{array}$} & \multicolumn{9}{|c|}{ Change from baseline in number of headache-free days with: } \\
\hline & \multicolumn{9}{|l|}{ CM study } \\
\hline & \multicolumn{3}{|l|}{ Month 1} & \multicolumn{3}{|l|}{ Month 2} & \multicolumn{3}{|l|}{ Month 3} \\
\hline & $\begin{array}{l}\text { Placebo } \\
(\mathrm{n}=89)\end{array}$ & $\begin{array}{l}675 / 225 \mathrm{mg} \\
(\mathrm{n}=87)\end{array}$ & $\begin{array}{l}900 \mathrm{mg} \\
(\mathrm{n}=85)\end{array}$ & $\begin{array}{l}\text { Placebo } \\
(\mathrm{n}=89)\end{array}$ & $\begin{array}{l}675 / 225 \mathrm{mg} \\
(\mathrm{n}=87)\end{array}$ & $\begin{array}{l}900 \mathrm{mg} \\
(\mathrm{n}=85)\end{array}$ & $\begin{array}{l}\text { Placebo } \\
(\mathrm{n}=89)\end{array}$ & $\begin{array}{l}675 / 225 \mathrm{mg} \\
(\mathrm{n}=87)\end{array}$ & $\begin{array}{l}900 \mathrm{mg} \\
(\mathrm{n}=85)\end{array}$ \\
\hline Could not perform household chores & $0.16(0.09)$ & $\begin{array}{l}0.08(0.10) \\
p=0.477\end{array}$ & $\begin{array}{l}-0.01(0.10) \\
p=0.1498\end{array}$ & $0.01(0.15)$ & $\begin{array}{l}0.36(0.15) \\
p=0.0892\end{array}$ & $\begin{array}{l}-0.07(0.15), \\
p=0.6952\end{array}$ & $0.04(0.12)$ & $\begin{array}{l}0.31(0.13) \\
p=0.1105\end{array}$ & $\begin{array}{l}0.05(0.13) \\
p=0.9495\end{array}$ \\
\hline \multicolumn{10}{|l|}{$\begin{array}{l}\text { Difficulty in concentration or mental } \\
\text { fatigue }\end{array}$} \\
\hline $\begin{array}{l}\text { No time working more slowly or } \\
\text { taking longer to complete tasks }\end{array}$ & $2.68(0.69)$ & $\begin{array}{l}4.13(0.76) \\
p=0.0975\end{array}$ & $\begin{array}{l}4.92(0.76) \\
p=0.014\end{array}$ & $3.76(0.80)$ & $\begin{array}{l}5.18(0.88) \\
p=0.1822\end{array}$ & $\begin{array}{l}6.48(0.89) \\
p=0.0133\end{array}$ & $4.22(0.86)$ & $\begin{array}{l}5.70(0.95) \\
p=0.202\end{array}$ & $\begin{array}{l}6.44(0.95) \\
p=0.0621\end{array}$ \\
\hline $\begin{array}{l}\text { Some of the time working more } \\
\text { slowly or taking longer to complete } \\
\text { tasks }\end{array}$ & $0.80(0.44)$ & $\begin{array}{l}1.13(0.49) \\
p=0.553\end{array}$ & $\begin{array}{l}1.21(0.49) \\
p=0.4733\end{array}$ & $0.97(0.52)$ & $\begin{array}{l}1.59(0.57) \\
p=0.3779\end{array}$ & $\begin{array}{l}0.75(0.58) \\
p=0.7557\end{array}$ & $1.04(0.55)$ & $\begin{array}{l}1.25(0.61) \\
p=0.7848\end{array}$ & $\begin{array}{l}1.24(0.61) \\
p=0.8014\end{array}$ \\
\hline $\begin{array}{l}\text { Half of the time working more slowly } \\
\text { or taking longer to complete tasks }\end{array}$ & $0.06(0.11)$ & $\begin{array}{l}-0.04(0.12) \\
p=0.4853\end{array}$ & $\begin{array}{l}0.16(0.12) \\
p=0.5506\end{array}$ & $-0.06(0.10)$ & $\begin{array}{l}0.07(0.11) \\
p=0.3455\end{array}$ & $\begin{array}{l}0.27(0.12) \\
p=0.0208\end{array}$ & $-0.00(0.13)$ & $\begin{array}{l}0.23(0.14) \\
p=0.1877\end{array}$ & $\begin{array}{l}0.30(0.14) \\
p=0.0989\end{array}$ \\
\hline $\begin{array}{l}\text { No time with difficulty } \\
\text { concentrating }\end{array}$ & $2.52(0.63)$ & $\begin{array}{l}4.20(0.64) \\
p=0.0305\end{array}$ & $\begin{array}{l}4.70(0.65) \\
p=0.0052\end{array}$ & $3.91(0.73)$ & $\begin{array}{l}5.55(0.74) \\
p=0.0305\end{array}$ & $\begin{array}{l}4.70(0.65) \\
p=0.0052\end{array}$ & $4.21(0.81)$ & $\begin{array}{l}6.07(0.83) \\
p=0.0856\end{array}$ & $\begin{array}{l}6.34(0.84) \\
p=0.049\end{array}$ \\
\hline $\begin{array}{l}\text { Some of the time have difficulty } \\
\text { concentrating }\end{array}$ & $1.00(0.36)$ & $\begin{array}{l}0.86(0.37) \\
p=0.7636\end{array}$ & $\begin{array}{l}0.66(0.37) \\
p=0.4478\end{array}$ & $0.79(0.46)$ & $\begin{array}{l}1.28(0.47) \\
p=0.4169\end{array}$ & $\begin{array}{l}0.94(0.47) \\
p=0.8042\end{array}$ & $1.35(0.52)$ & $\begin{array}{l}0.70(0.53) \\
p=0.3582\end{array}$ & $\begin{array}{l}0.75(0.53) \\
p=0.394\end{array}$ \\
\hline $\begin{array}{l}\text { Most of the time have difficulty } \\
\text { concentrating }\end{array}$ & $-0.21(0.11)$ & $\begin{array}{l}0.12(0.12) \\
p=0.0267\end{array}$ & $\begin{array}{l}0.01(0.12) \\
p=0.1325\end{array}$ & $-0.14(0.13)$ & $\begin{array}{l}0.23(0.13) \\
p=0.0347\end{array}$ & $\begin{array}{l}0.02(0.13) \\
p=0.3565\end{array}$ & $-0.10(0.13)$ & $\begin{array}{l}0.16(0.13) \\
p=0.1205\end{array}$ & $\begin{array}{l}-0.10(0.13), \\
p=0.9994\end{array}$ \\
\hline $\begin{array}{l}\text { All of the time have difficulty } \\
\text { concentrating }\end{array}$ & $0.05(0.07)$ & $\begin{array}{l}0.02(0.07) \\
p=0.777\end{array}$ & $\begin{array}{l}0.02(0.07) \\
p=0.6987\end{array}$ & $-0.03(0.15)$ & $\begin{array}{l}0.25(0.15) \\
p=0.1714\end{array}$ & $\begin{array}{l}0.01(0.15) \\
p=0.8761\end{array}$ & $0.03(0.12)$ & $\begin{array}{l}0.24(0.13) \\
p=0.2089\end{array}$ & $\begin{array}{l}0.07(0.13) \\
p=0.7893\end{array}$ \\
\hline $\begin{array}{l}\text { No time feeling very tired, asleep, or } \\
\text { feeling drained }\end{array}$ & $2.84(0.60)$ & $\begin{array}{l}3.43(0.62) \\
p=0.4269\end{array}$ & $\begin{array}{l}4.61(0.62) \\
p=0.0179\end{array}$ & $4.00(0.74)$ & $\begin{array}{l}5.09(0.76) \\
p=0.2604\end{array}$ & $\begin{array}{l}5.88(0.76) \\
p=0.0528\end{array}$ & $4.61(0.83)$ & $\begin{array}{l}5.75(0.85) \\
p=0.3016\end{array}$ & $\begin{array}{l}6.31(0.85) \\
p=0.1226\end{array}$ \\
\hline $\begin{array}{l}\text { Some of the time feeling very tired, } \\
\text { asleep, or feeling drained }\end{array}$ & $0.41(0.44)$ & $\begin{array}{l}1.56(0.45) \\
p=0.0355\end{array}$ & $\begin{array}{l}0.98(0.45) \\
p=0.2904\end{array}$ & $0.33(0.54)$ & $\begin{array}{l}1.77(0.55) \\
p=0.0423\end{array}$ & $\begin{array}{l}1.01(0.55) \\
p=0.3333\end{array}$ & $0.77(0.57)$ & $\begin{array}{l}0.96(0.59) \\
p=0.805\end{array}$ & $\begin{array}{l}0.81(0.59) \\
p=0.9629\end{array}$ \\
\hline $\begin{array}{l}\text { Most of the time feeling very tired, } \\
\text { asleep, or feeling drained }\end{array}$ & $-0.06(0.17)$ & $\begin{array}{l}0.13(0.18) \\
p=0.3707\end{array}$ & $\begin{array}{l}-0.05(0.18) \\
p=0.9583\end{array}$ & $0.17(0.22)$ & $\begin{array}{l}0.18(0.22) \\
p=0.992\end{array}$ & $\begin{array}{l}-0.12(0.22) \\
p=0.3012\end{array}$ & $0.08(0.21)$ & $\begin{array}{l}0.03(0.22) \\
p=0.8635\end{array}$ & $\begin{array}{l}-0.22(0.22) \\
p=0.2717\end{array}$ \\
\hline $\begin{array}{l}\text { All of the time feeling very tired, } \\
\text { asleep, or feeling drained }\end{array}$ & $0.07(0.12)$ & $\begin{array}{l}-0.03(0.13) \\
p=0.5428\end{array}$ & $\begin{array}{l}-0.05(0.13) \\
p=0.4612\end{array}$ & $-0.06(0.18)$ & $\begin{array}{l}0.17(0.18) \\
p=0.3291\end{array}$ & $\begin{array}{l}0.00(0.18) \\
p=0.7989\end{array}$ & $-0.07(0.25)$ & $\begin{array}{l}0.38(0.25) \\
p=0.1881\end{array}$ & $\begin{array}{l}0.26(0.25) \\
p=0.3404\end{array}$ \\
\hline
\end{tabular}

Abbreviations: ANCOVA = analysis of covariance; CM = chronic migraine; HFEM = high-frequency episodic migraine; LSM = least square mean. 
functional performance compared to placebo. This is an important observation because many preventive migraine therapies are known to have a variety of side effects (e.g., cognitive difficulties) that can contribute to interictal symptom burden and reduce medication adherence and persistence. ${ }^{19,20}$

Acute medications for migraine management are often administered at the onset of headache but in a subset of patients may be taken on headache-free days as a form of anticipatory treatment, especially if prodromal symptoms are experienced, in an attempt to preempt the headache phase. In addition, patients may use an acute treatment in the absence of headache as an anxiety response out of fear of having a headache (cephalalgiaphobia). ${ }^{21,22}$ With more headache-free days, patients may have reduced intake of acute treatments, resulting in reduction of any associated side effects that may contribute to impaired functional performance on headache-free days. Overall, patients taking fremanezumab significantly reduced their use of acute medication by 5 and $6.5 \mathrm{~d} / \mathrm{mo}$ compared to the reduction of 3 and $4 \mathrm{~d} / \mathrm{mo}$ for those taking placebo during the HFEM and CM studies. ${ }^{13,14}$ We do not know specifically whether the use of acute medications decreased on headache vs headache-free days. A future study should take into account a potential change in acute medications due to the use of a preventive treatment in evaluating functional performance.

Another possibility is that there is an effect on more than just the headache phase of the attack but also prodrome-, postdrome-, or interictal-phase symptoms on headache-free days. The prodrome phase of migraine is believed to be centrally mediated, likely at the level of the hypothalamus. ${ }^{23}$ Although CGRP-monoclonal antibodies are not believed to cross the blood-brain barrier because their high molecular weight, it is possible that fremanezumab could directly affect central networks. One possibility is that fremanezumab may reduce CGRP-mediated transmission in the trigeminovascular system and that this reduction in peripheral afferent activity may modulate the central networks that generate the migraine attack. $^{24,25}$ In a study examining saliva CGRP levels throughout migraine phases in patients with EM, a statistically significant increase of CGRP was found during the premonitory, mild headache, and moderate to severe headache phases compared to levels in the baseline and resolution phases. ${ }^{26}$ Pretreatment interheadache CGRP levels in patients with $\mathrm{CM}$ have also been shown to be significantly higher in responders to onabotulinumtoxinA compared to nonresponders, and 1 month after treatment, CGRP decreased in responders but not in nonresponders. ${ }^{27}$ Our patients were not surveyed for prodrome and postdrome symptoms, so a comparison between such symptoms and their reported functional status is not possible. It would be of interest for future studies to see whether fremanezumab has an effect on these symptoms and how this relates to its proposed mechanism of action and its effect overall on disease burden.

Another explanation is that modulation of CGRP affects comorbid conditions such as depression, anxiety, irritable bowel syndrome, and other chronic pain disorders that were not assessed. Animal models have shown a role for CGRP in depression-like behaviors and in anxiety-related neural pathways. ${ }^{28-31}$ CGRP has been studied in a variety of pain syndromes, including fibromyalgia ${ }^{32}$ and visceral pain. ${ }^{33}$ $\beta$-CGRP has also been reported as modulating the autonomic visceral control in the gut. ${ }^{34}$ Future studies should evaluate the effect of CGRP-modulating therapies on the symptoms of associated comorbid diseases.

As with all clinical trials, a potential limitation of our study is that patients may have become unblinded during the study because of differences in the side effects between the active treatment and placebo treatment, which may have affected reporting. Given the low rate of reported adverse events that occurred in the HFEM and CM studies, it is very unlikely that any unblinding due to adverse event differences had a substantial effect on the results. Another limitation of our study includes the fact that our assessment of function was not based on standardized questionnaires such as the Headache Impact Test-6 or the Migraine-Specific Quality of Life Questionnaire. However, these measures ask about the last 4 weeks and do not distinguish ictal and interictal burden. We believe that reports from a daily diary asking about the last day provide a face-valid method of assessing self-reported function on a particular day. Daily diary measures are not subject to recall bias and are recommended as an additional measure to retrospective quality-of-life assessments. ${ }^{35}$ Nonetheless, validation of these measures is needed. The clinical meaningfulness of the increased number of headache-free days with normal function was not evaluated; therefore, direct comparison to other types of health-related quality-of-life assessments in migraine is needed in future studies. ${ }^{36,37}$ However, recognizing that in headache clinical trials a difference of 1 headache day per month is clinically meaningful along with a 30\% reduction headache frequency, we can surmise that our findings may be clinically meaningful. ${ }^{38}$

The strength of this study is that it introduces a novel and potentially clinically meaningful endpoint that, if confirmed in future studies, facilitates the measurement of more comprehensive outcomes for patients and raises a host of questions about the mechanism of action of this class of biologics and the mechanism of disease in migraine.

Our study reports increased headache-free days with normal function for patients on fremanezumab treatment during the HFEM and CM studies. Further prospective research on the effect of CGRP monoclonal antibodies on headache-free days is warranted. Evaluating the effect of CGRP-modulating therapies on functional performance during headache-free days and on nonheadache symptoms may help provide insight into potential pathophysiologic mechanisms of migraine and may assist in determining the role of CGRP monoclonal antibodies such as fremanezumab in the pathophysiology of migraine and on the influence of CGRP and its blockade on migraine-related comorbid diseases. 


\section{Author contributions}

J.V., D.W.D., R.B.L., P.S.L., Y.M., and M.E.B. designed the post hoc analyses and discussed the interpretation of the results. Y.M. created the statistical analysis plan, analyzed and interpreted data. J.V. and P.S.L. wrote the first draft of the manuscript. All authors participated in the writing and editing of the manuscript and approved its content.

\section{Acknowledgment}

The authors appreciate the dedication of the patients who participated in the studies and the investigators who led and conducted the HFEM and CM studies of fremanezumab. Special thanks go to Mirna McDonald and Bo Jiang (Biostatistics, Teva Pharmaceutical Industries, Frazer, PA) for their assistance in the statistical analyses.

\section{Study funding}

The EM and CM phase 2 studies of fremanezumab described in this report were funded by Global Specialty Research and Development Teva Pharmaceutical Industries Ltd (Netanya Israel).

\section{Disclosure}

J. VanderPluym reports speaking fees for Amgen and Novartis and consulting for Healint. D. Dodick has received compensation from serving on advisory boards and/or consulting from Allergan, Amgen, Novartis, Alder, Arteaus, Pfizer, Colucid, Merck, NuPathe, Eli Lilly and Company, Autonomic Technologies, Ethicon J\&J, Zogenix, Supernus, Labrys, Boston Scientific, Medtronic, St Jude, Bristol-Myers Squibb, Lundbeck, Impax, MAP, Electrocore, Tonix, Novartis, Teva, Alcobra, Zosano, Insys, Ipsen, GBS/Nocira, Acorda, eNeura, Charleston Laboratories, Gore, Biohaven, Bioventric, Magellan, Theranica, Xenon, and Dr Reddy's/Promius Pharma. Dr Dodick owns equity in Epien, GBS/Nocira, Second Opinion, Healint, and Theranica. Dr Dodick has received funding for travel, speaking, editorial activities, or royalty payments from IntraMed, SAGE Publishing, Sun Pharma, Allergan, Oxford University Press, American Academy of Neurology, American Headache Society, West Virginia University Foundation, Canadian Headache Society, Healthlogix, Universal Meeting Management, WebMD, UptoDate, Medscape, Oregon Health Science Center, Albert Einstein University, University of Toronto, Starr Clinical, Decision Resources, Synergy, MedNet LLC, Peer View Institute for Medical Education, Medicom, Chameleon Communications, Academy for Continued Healthcare Learning, Haymarket Medical Education, Global Scientific Communications, HealthLogix, Miller Medical, MeetingLogiX, and Wiley Blackwell. Dr Dodick, through his employer, has consulting use agreements with NeuroAssessment Systems and Myndshft. He holds board of director positions with KingDevick Technologies, and Epien Inc. He holds the following patent: 17189376.1-1466:vTitle: Botulinum Toxin Dosage Regimen for Chronic Migraine Prophylaxis (no compensation). R. Lipton reports grants and personal fees from Alder,
Allergan, CoLucid, Electrocore, and Novartis; personal fees and other from eNeura; personal fees from Ethicon, Merck, Labrys, Autonomic Technologies, Boston Scientific, BristolMyers Squibb, Dr Reddy's Laboratories, Eli Lilly, Endo Pharmaceuticals, Informa, Teva Pharmaceuticals, and Vedanta; and grants from Migraine Research Fund, National Headache Foundation, and NIH. Y. Ma and P. Loupe are employees of the Innovative Research and Development division of Teva Pharmaceutical Industries Ltd. M. Bigal is a former employee of Teva Pharmaceuticals and is now senior vice president and chief medical officer of Purdue Pharma. Go to Neurology.org/ $\mathrm{N}$ for full disclosures.

Received August 23, 2017. Accepted in final form June 25, 2018.

\section{References}

1. Lipton RB, Stewart WF, Diamond S, Diamond ML, Reed M. Prevalence and burden of migraine in the United States: data from the American Migraine Study II. Headache 2001;41:646-657.

2. Buse DC, Manack AN, Fanning KM, et al. Chronic migraine prevalence, disability, and sociodemographic factors: results from the American Migraine Prevalence and Prevention Study. Headache 2012;52:1456-1470.

3. Natoli JL, Manack A, Dean B, et al. Global prevalence of chronic migraine: a systematic review. Cephalalgia 2010;30:599-609.

4. Headache Classification Committee of the International Headache Society. The International Classification of Headache Disorders, 3rd Edition (Beta Version) Cephalalgia 2013;33:629-808.

5. GBD 2015 Disease and Injury Incidence and Prevalence Collaborators. Global, regional, and national incidence, prevalence, and years lived with disability for 310 diseases and injuries, 1990-2015: a systematic analysis for the Global Burden of Disease Study 2015. Lancet 2016;388:1545-1602.

6. Lampl C, Thomas H, Stovner LJ, et al. Interictal burden attributable to episodic headache: findings from the Eurolight project. J Headache Pain 2016;17:9.

7. Coppola G, Pierelli F, Schoenen J. Habituation and migraine. Neurobiol Learn Mem 2009;92:249-259.

8. Blau JN. Migraine prodromes separated from the aura: complete migraine. Br Med J 1980;281:658-660.

9. Blau JN. Migraine postdromes: symptoms after attacks. Cephalalgia 1991;11: 229-231.

10. Maniyar FH, Sprenger T, Monteith T, Schankin CJ, Goadsby PJ. The premonitory phase of migraine: what can we learn from it? Headache 2015;55:609-620.

11. Giffin NJ, Ruggiero L, Lipton RB, et al. Premonitory symptoms in migraine: an electronic diary study. Neurology 2003;60:935-940.

12. Giffin NJ, Lipton RB, Silberstein SD, Olesen J, Goadsby PJ. The migraine postdrome: an electronic diary study. Neurology 2016;87:309-313.

13. Bigal ME, Dodick DW, Rapoport AM, et al. Safety, tolerability, and efficacy of TEV48125 for preventive treatment of high-frequency episodic migraine: a multicentre, randomised, double-blind, placebo-controlled, phase $2 \mathrm{~b}$ study. Lancet Neurol 2015; 14:1081-1090.

14. Bigal ME, Edvinsson L, Rapoport AM, et al. Safety, tolerability, and efficacy of TEV48125 for preventive treatment of chronic migraine: a multicentre, randomised, double-blind, placebo-controlled, phase $2 \mathrm{~b}$ study. Lancet Neurol 2015;14: 1091-1100.

15. Silberstein SD, Dodick DW, Bigal ME et al. Fremanezumab for the preventive treatment of chronic migraine. N Engl J Med 2017;377:2113-2122.

16. Bigal M, Dodick D, Krymchantowski AV, et al. TEV-48125 for the preventive treatment of chronic migraine: efficacy at early time points. Neurology 2016;87:1-8.

17. Aycardi E, Bigal M, McDonald M. Fremanezumab (formerly TEV-48125) reduces headache pain within the first week of beginning treatment in the phase 2 episodic migraine study: presented at the American Headache Society abstract IOR5. Headache 2017;57( suppl 3):I29.

18. US Department of Health and Human Services Food and Drug Administration. Multiple endpoints in clinical trials guidance for industry draft guidance. 2017. Available at: fda.gov/downloads/drugs/guidancecomplianceregulatoryinformation/ guidances/ucm536750.pdf. Accessed May 15, 2018.

19. Silberstein SD. Topiramate in migraine prevention: a 2016 perspective. Headache 2017;57:165-178.

20. Hepp Z, Bloudek LM, Varon SF. Systematic review of migraine prophylaxis adherence and persistence. J Manag Care Pharm 2014;20:22-33.

21. Peres MF, Mercante JP, Guendler VZ, et al. Cephalalgiaphobia: a possible specific phobia of illness. J Headache Pain 2007;14:56-59.

22. Giannini G, Zanigni S, Grimaldi D, et al. Cephalalgiaphobia as a feature of high frequency migraine: a pilot study. J Headache Pain 2013;14:49.

23. Maniyar FH, Sprenger T, Monteith T, Schankin C, Goadsby PJ. Brain activations in the premonitory phase of nitroglycerin triggered migraine attacks. Brain 2014;137: $232-242$. 
24. Eftekhari S, Salvatore CA, Johansson S, Chen T, Zeng Z, Edvinsson L. Localization of CGRP, CGRP receptor, PACAP and glutamate in trigeminal ganglion: relation to the blood-brain barrier. Brain Res 2015;1600:93-109.

25. Goldberg SW, Siberstein SD. Targeting CGRP: a new era for migraine treatment. CNS Drugs 2015;29:443-452.

26. Cady RK, Vause CV, Ho TW, Bigal ME, Durham PL. Elevated saliva calcitonin generelated peptide levels during acute migraine predict therapeutic response to rizatriptan. Headache 2009;49:1258-1266.

27. Cernuda-Morollon E, Ramon C, Martinez-Camblor P, Serrano-Pertierra E, Larrosa D, Pascual J. OnabotulinumtoxinA decreases interictal CGRP plasma levels in patients with chronic migraine. Pain 2015;156:820-824.

28. Shao B, Zhou YL, Wang H, Lin YS. The role of calcitonin gene-related peptide in poststroke depression in chronic mild stress-treated ischemic rats. Physiol Behav 2015, 139:224-230.

29. Sink KS, Walker DL, Yang Y, Davis M. Calcitonin gene-related peptide in the bed nucleus of the stria terminalis produces an anxiety-like pattern of behavior and increases neural activation in anxiety-related structures. J Neurosci 2011;31: 1802-1810.

30. Schorscher-Petcu A, Austin JS, Mogil JS, Quirion R. Role of central calcitonin generelated peptide (CGRP) in locomotor and anxiety- and depression-like behaviors in two mouse strains exhibiting a CGRP-dependent difference in thermal pain sensitivity. J Mol Neurosci 2009;39:125-136.
31. Gungor NZ, Pare D. CGRP inhibits neurons of the bed nucleus of the stria terminalis: implications for the regulation of fear and anxiety. J Neurosci 2014:34:60-65.

32. Vaeroy H, Sakurada T, Forre O, Kass E, Terenius L. Modulation of pain in fibromyalgia (fibrosis syndrome) cerebrospinal fluid (CSF): investigation of pain related neuropeptides with special reference to calcitonin gene-related peptide (CGRP). J Rheumatol 1989;16(suppl 19):94-97.

33. Schou WS, Ashina S, Amin FM, Goadsby P, Ashina M. Calcitonin gene-related peptide and pain: a systematic review. J Headache Pain 2017;18:34.

34. Evangelista S. Capsaicin receptor as target of calcitonin gene-related peptide in the gut. In: Abdel-Salam OME, editor. Capsaicin as a Therapeutic Molecule, Progress in Drug Research. vol 68. Basel: Springer; 2014.

35. Burton WN, Landy SH, Downs KE, Runken C. The impact of migraine and the effect of migraine treatment on workplace productivity in the United States and suggestions for future research. Mayo Clin Proc 2009;84:436-445.

36. Lipton RB, Rosen NL, Ailani J, DeGryse RE, Gillard PJ, Varon SF. OnabotulinumtoxinA improves quality of life and reduces impact of chronic migraine over one year of treatment: pooled results from the PREEMPT randomized clinical trial program. Cephalalgia 2016;36:899-908.

37. Lipton RB, Varon SF, Grosberg B, et al. OnabotulinumtoxinA improves quality of life and reduces impact of chronic migraine. Neurology 2011;77:1465-1472.

38. Dodick DW, Turkel CC, DeGryse RE, et al. Assessing clinically meaningful treatment effects in controlled trials: chronic migraine as an example. J Pain 2015;16:164-175. 


\section{Neurology}

\section{Fremanezumab for preventive treatment of migraine: Functional status on headache-free days \\ Juliana VanderPluym, David W. Dodick, Richard B. Lipton, et al.}

Neurology 2018;91;e1152-e1165 Published Online before print August 17, 2018

DOI 10.1212/01.wnl.0000544321.19316.40

This information is current as of August 17, 2018

\section{Updated Information \& Services}

References

Citations

Subspecialty Collections

Permissions \& Licensing

Reprints including high resolution figures, can be found at: http://n.neurology.org/content/91/12/e1152.full

This article cites 36 articles, 7 of which you can access for free at: http://n.neurology.org/content/91/12/e1152.full\#ref-list-1

This article has been cited by 7 HighWire-hosted articles: http://n.neurology.org/content/91/12/e1152.full\#\#otherarticles

This article, along with others on similar topics, appears in the following collection(s):

All Headache

http://n.neurology.org/cgi/collection/all_headache Migraine

http://n.neurology.org/cgi/collection/migraine

Information about reproducing this article in parts (figures,tables) or in its entirety can be found online at:

http://www.neurology.org/about/about_the_journal\#permissions

Information about ordering reprints can be found online:

http://n.neurology.org/subscribers/advertise

Neurology ${ }^{\circledR}$ is the official journal of the American Academy of Neurology. Published continuously since 1951, it is now a weekly with 48 issues per year. Copyright Copyright ( 2018 The Author(s). Published by Wolters Kluwer Health, Inc. on behalf of the American Academy of Neurology.. All rights reserved. Print ISSN: 0028-3878. Online ISSN: 1526-632X.

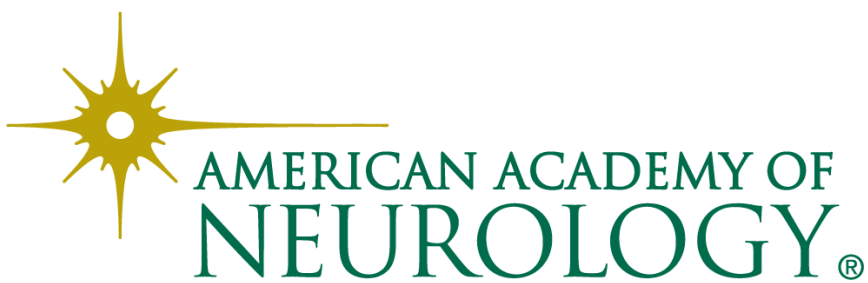

